\title{
MENAKSIR KESETARAAN GENDER DALAM PROFESI OJEK ONLINE PEREMPUAN DI KOTA MALANG
}

\section{Faizal Kurniawan ${ }^{1}$, Siti Fatimah Soenaryo ${ }^{2}$}

${ }^{1}$ Program Studi Pendidikan Sejarah dan Sosiologi IKIP Budi Utomo Malang

${ }^{2}$ Program Studi PGSD Universitas Muhammmadiyah Malang

${ }^{1}$ Email : faizal.pssbu@ gmail.com

\begin{abstract}
Abstrak
Penelitian ini mengkaji secara mendalam tentang kegelisahan akademik yang menyeruak di kalangan akademisi tentang kemunculan fenomena tukang ojek online (daring) perempuan di Kota Malang. Dari data wawancara lapangan, mulai tahun 2016 semenjak transportasi online berkembang di Kota Malang, setidaknya hampir 30\% pertumbuhan pengemudi ojek online diisi perempuan. Penelitian ini menggunakan metode studi kasus di Kota Malang. Tesis dari penelitian ini adalah munculnya asumsi dalam konteks gender bahwa rasionalitas pemilih profesi sebagai ojek online tidak hanya dari alasan ekonomi semata, melainkan adanya perubahan dinamika sosial yang terjadi di masyarakat. Bagi Foucault, fenomena gender bisa dikatakan sebagai diskursus yang nantinya membangun konsep kultur. Idealisme dan romantismenya, perempuan butuh pekerjaan tidak hanya sebagai tuntutan ekonomi saja, tetapi juga pergeseran gender bahwa perempuan tidak hanya mengurusi pekerjaan rumah semata. James Coleman memandang dalam kacamata rasionalitas bahwa pilihan menjadi driver ojek online adalah sebuah "Jalan Pintas" untuk mendapatkan uang. Secara singkat bahwa pertumbuhan driver perempuan ini sebaiknya dapat disikapi secara bijak oleh setiap elit pemangku kebijakan utamanya berbasis revolusi industri 4.0 .
\end{abstract}

Kata kunci: gender; profesi; ojek online perempuan; kota malang

\section{EXAMINE GENDER EQUALITY TO WOMAN ONLINE DRIVER IN MALANG CITY}

\begin{abstract}
This study examines in depth the academic anxiety that has arisen among academics about the emergence of the phenomenon of women online motorcycle taxi drivers in the city of Malang. As we have realized, the emergence of female online motorcycle taxi drivers has grown along with the development of online transportation in the city of Malang. From the interview data obtained, starting in 2016 since online transportation has grown in Malang, at least almost $30 \%$ growth in recruitment of women online motorcycle taxi drivers. This research uses the case study method. The thesis of this research is the rise the opinion for the gender context itself that the rationality of professional voters as an online motorcycle taxi is not only from economic reasons alone, but also the existence of social dynamics housing that occurs in the community. For Foucault, gender phenomena can be said to be a discourse that will later develop the concept of a culture. Its idealism and romanticism, women need jobs not only as economic demands, but also gender shifts that women do not only take care of homework. James Coleman sees in the perspective rationality that the choice to be an online motorcycle taxi driver is a "Shortcut" to get money for women. In addition, this research should be able to be a further study of elite policy makers to make more attention to labor laws, especially those based on the industrial revolution 4.0.
\end{abstract}

\section{Keywords: gender; profession; woman online taxi driver; Malang city}




\section{LATAR BELAKANG}

Menyoal keberadaan ojek online di kota Malang tak lepas dari sebuah perdebatan tentang manfaat dari sebuah eksistensi transportasi berbasis online (daring) yang telah banyak dirasakan. Aplikasi yang cukup popular di kalangan masyarakat yaitu Grab sebagai aplikator buatan Malaysia dan Gojek sebagai aplikator buatan anak negeri dengan Nadiem Makarim dan Michaelangelo Moran, Rifaldi sebagai punggawanya. Aplikasi transportasi online Gojek dan Grab ini adalah salah satu aplikator yang menggunakan konsep Big Data sebagai dasar kerja atau blue print. Megantara (2016) mengungkapkan konsep Big Data adalah sebuah trend yang mencakup area luas dalam lingkup teknologi dan bisnis, menunjuk pada teknologi dan inisiatif yang melibatkan data begitu beragam, cepat berubah, dan memiliki ukuran yang sangat besar.

Aplikasi Gojek dan Grab di Kota Malang mulai beraktifitas dan mulai mencapai puncaknya pada tahun 2016, dengan ditunjukkan banyaknya fasilitas yang diberikan oleh aplikasi Grab dan Gojek seperti layanan pengantaran barang dan penyedia jasa pembelian makanan dan pembelian tiket, termasuk jasa pengiriman barang lainnya (Nugroho, 2016). Selain itu, apabila dibandingkan dengan transportasi konvensional lainnya, tarif konvensional sering "memalak" tarif diluar batas yang telah ditentukan oleh Dinas Perhubungan. Hal ini diperkuat dengan Survey Yayasan Lembaga Konsumen Indonesia (YKLI) yang mengungkapkan alasan kenapa masyarakat memilikh angkutan transportasi yang berbasis aplikasi berturut turut sebagai berikut yakni murah $(84,1 \%)$, cepat $(81,9 \%)$, nyaman $(79 \%)$ dan aman (61\%). Berkembangnya transportasi online tersebut juga membawa perubahan sosial bagi masyarakat penggunanya. Sistem sosial dan kebiasaan masyarakat juga berubah seiring adanya aplikasi yang sangat memudahkan bagi masyarakat millennial di Kota Malang. Pengguna tersebut tidak hanya sebagai konsumen, tetapi juga sebagai seller atau penyedia jasa (Anindita, 2016). Banyak usaha kuliner yang bergabung dengan kedua aplikasi ini untuk menunjang perkembangan usahanya. Syarat untuk bergabung menjadi mitra dari kedua aplikasi tersebut juga tidak memerlukan modal yang terlalu besar.

Seiring pesatnya perkembangan pengguna dua aplikasi transportasi online tersebut, driver atau pengemudi online dari tahun ke tahun terus mengalami pertumbuhan. Tidak hanya didominasi oleh kaum Adam, kaum hawa mulai ikut berpartisipasi dalam kemitraan bisnis yang dijalankan oleh dua aplikator besar ini. Penelusuran awal tercatat 500 lebih driver perempuan di tahun 2016 yang mendaftar menjadi mitra baik itu Gojek maupun Grab di Kota Malang. Alasan yang mereka ungkapkan pada wawancara awal, bergabung menjadi mitra pun berbeda-beda. Alasan ekonomi tidak hanya menjadi alasan utama bagi driver perempuan untuk memilih pekerjaan sebagai pengemudi ojek. Sebagai sebuah isu feminisme, hal ini sangat menarik untuk diperbincangkan dan dibahas, mengingat stereotip yang masih mengakar kuat di masyarakat adalah perempuan tidak cocok kerja di jalanan atau kerja lapangan yang sangat mengedepankan fisik. Emansipasi yang terus menurus dipoles, akan terus mendorong kaum perempuan untuk tetap memperjuangkan kesetaraannya dengan laki-laki (Verastiwi, 2018). Bisa dikatakan bahwa faktor ekonomi tidak lagi diterima sebagai tesis awal. Konsep kemandirian perempuan juga melalui sebuah profesi pekerjaan yang telah dilakoninya.

Permasalahan mendasar yang muncul adalah bagaimana perempuan yang berprofesi sebagai pengemudi dalam ojek online ini mengkonstruksikan dirinya di masyarakat. Benar, bahwa perempuan membutuhkan aktualisasi dan eksistensi sebagai bagian dari perjuangan hidup. Merujuk pada penelitian sebelumnya bahwa penelitian gender tidak cukup dengan hanya fokus dalam pengkajian saja, wujud tindakan riil lebih utama berupa pendampingan melalui Focus Group Discussion (FGD) (Hani, 2018). Fakta yang mengemuka di lapangan sering kali pengemudi ojek online perempuan lebih memilih mengalah daripada pengemudi ojek online laki-laki. Hal ini bisa dimafhumi ketika melihat di sebuah tempat atau 
mangkal banyak didominasi laki-laki, maka secara perlahan pengemudi ojek online perempuan tersebut enggan untuk ikut berpartisipasi karena menyadari kapasitas diri sebagai perempuan dan juga merasa risih dengan cuitan dan bahkan godaan yang diberikan oleh teman laki-laki yang seprofesi dengannya (Perguna, 2019). Seringkali juga pengemudi ojek daring perempuan mendapatkan perlakuan tidak sopan, seronok bahkan sudah menjurus kepada kekerasan simbolik baik verbal maupun non verbal. Pendampingan pun juga banyak dilakukan sebagai bentuk penguatan terhadap peran perempuan dalam konteks profesi ojek online. Perempuan dalam konteks ini acap menjadi korban konstruksi sosial yang diciptakan oleh masyarakat bahwa objek perempuan adalah figur yang lemah dan objek kekerasan. Sosialisasi gender dapat direproduksi melalui kelembagaan sosial (Marhumah, 2011). Kelembagaan ini diharapkan dapat berperan sebagai lembaga sosial profesi ojek daring.

\section{METODE PENELITIAN}

Penelitian ini menggunakan pendekatan studi kasus. Studi kasus dirasakan tepat untuk penelitian yang mempunyai keterbatasan waktu dan keunikannya dengan kebutuhan analisis data yang mendalam tentang studi gender pada profesi ojek online perempuan ini. Pemilihan terhadap metode studi kasus akan dapat mengungkapkan secara mendalam dengan waktu yang terbatas (Qoriah, 2008). Penelitian ini terbagi dalam 3 tahapan yaitu observasi, wawancara, dan dokumentasi. Kegiatan penelitian dilaksanakan pada bulan September 2018 sampai bulan Agustus tahun 2019, pemilihan waktu tersebut didasarkan pada hasil observasi peneliti terhadap intensitas pengguna atau pelamar sebagai mitra grab dan gojek sebagai aplikator tersebut sedang mencapai puncaknya. Pada rentan waktu tersebut juga terdapat dinamika proses pro dan kontra terhadap keberadaan aplikator tersebut dan juga adanya proses risistensi atau perjuangan kenaikan tarif yang diperjuangkan oleh kebanyakan driver aplikator gojek dan grab ini.

Data primer dari penelitian ini adalah hasil wawancara langsung dengan driver perempuan dari grab dan gojek. Sedangkan data sekunder bersifat mendukung penelitian ini seperti buku kepustakaan dan screenshoot yang didapatkan dari forum media sosial antar sesama driver gojek dan grab yang ada di kota Malang. Penelitian ini bertempat di Kota Malang tepatnya di kawasan klojen, sukun, penanggungan dan blimbing. Skema aplikator grab dan gojek pun mempunyai intensitas lebih di kawasan ini. Selain itu pengguna jenis aplikator ini juga kebanyakan di area tersebut.

Fokus pemilihan subjek penelitian yaitu pengemudi perempuan yang aktif dalam menjalankan profesinya sebagai seorang driver ojek online. Pada dasarnya memilih dengan tujuan menggali data akan menentukan kualitas data yang diperoleh dalam penelitian. Menggali data dilakukan dengan depth interview yang menghasilkan data akurat serta dapat dipertanggungjawabkan dengan proses triangulasi data. Proses triangulasi dilakukan pada waktu Focus Group Discussion (FGD). Rancangan dari penelitian ini adalah dengan mengkaji dari kerangka berpikir konsep gender yang menyatakan bahwa perempuan memiliki fungsi reproduksi, kontruksi sosial gender perempuan dalam profesi ojek online dan bagaimana peran wanita dalam produktifitasnya sebagai manusia (lihat gambar 1)

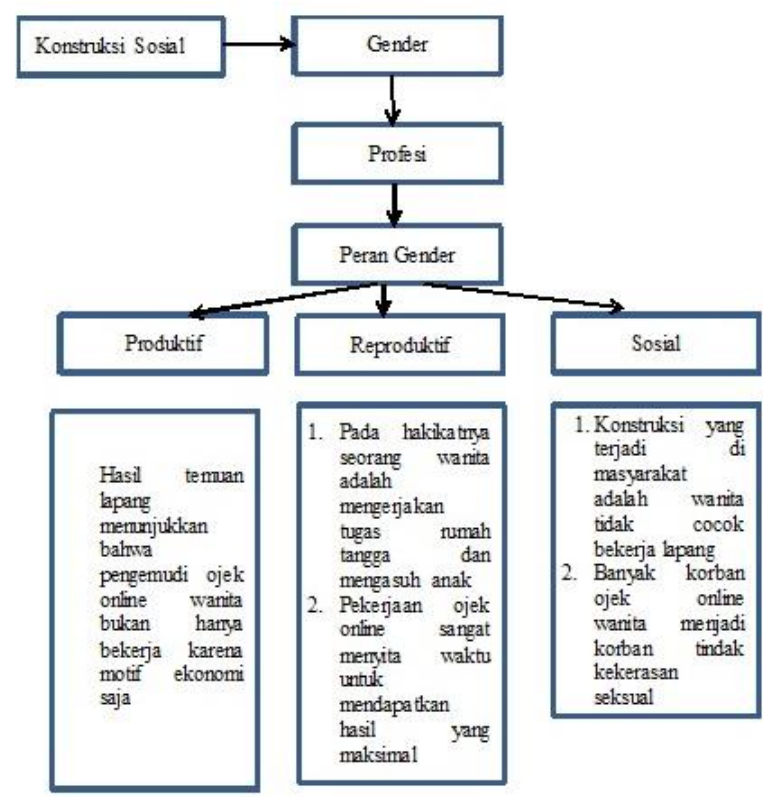

Gambar 1. Kerangka berpikir studi gender ojek online perempuan 


\section{HASIL DAN PEMBAHASAN}

\section{Ojek Online Perempuan dan Produktifitas di Kota Malang}

Bagi sebagaian besar perempuan yang bekerja sebagai ojek online di Kota Malang, profesi ini merupakan sebuah "jalan pintas" bagi kaum perempuan yang ingin mencari penghasilan yang tergolong lumayan dengan persyaratan yang tidak membutuhkan pendidikan tinggi, menjadi driver online. Dari data yang ditemukan bahwa pengguna aplikasi transportasi online di kota Malang terus meningkat hampir mendekati $80 \%$ tiap tahunnya. Hal ini menjadi mendorong perusahaan Grab dan Gojek untuk menambah mitra pengemudinya. Bertambahnya mitra yang dilayani seharusnya juga dibarengi dengan peningkatan jumlah pengemudi. Peningkatan jumlah pengemudi tak hanya pada laki-laki tetapi juga perempuan yang terus bertambah. Hal ini diamine oleh Teguh salah satu officer dari kantor Grab Malang yang menyebut peningkatan jumlah pengemudi perempuan khususnya di kota malang meningkat hampir $200 \%$ (lihat tabel 1).

\begin{tabular}{lccc}
\hline \multirow{2}{*}{ No } & \multicolumn{3}{c}{ Jumlah Driver Per Tahun } \\
\cline { 2 - 4 } & $\mathbf{2 0 1 7}$ & $\mathbf{2 0 1 8}$ & $\mathbf{2 0 1 9}$ \\
\hline 1 & 200 Orang & 350 Orang & 700 Orang \\
\hline
\end{tabular}

Tabel 1. Perkembangan Jumlah Driver Ojek Online Perempuan

Dari tabel 1 sangat terlihat signifikansi kenaikan yang berbanding lurus pula dengan kenaikan konsumen (pengguna) dari aplikasi tersebut. Penumbuhan ini dimaklumi karena setting sosial Malang raya yang dikenal dengan ragam destinasinya. Sebagai kota pendidkan kota Malang memiliki tiga kampus negeri dan beberapa kampus swasta yang tersebar. Kota Batu sebagai kota wisata juga memanjakan dengan dihadirkan wahana wisata yang megah dan kekinian. Destinasi menarik ini menjadi magnet tersendiri dan pada gilirannya memunculkan pilihan rasional konsumen dalam mendukung aktivitas baik sehari-hari maupun aktivitas leisure mereka untuk memilih menggunakan angkutan yang berbasis online daripada yang bersifat konvensional. Menaksir larisnya aplikasi Grab dan Gojek di Kota Malang mendorong sebagian perempuan untuk beralih dan menjadi bagian mitra dari Grab dan Gojek. Dorongan untuk menjadi pengemudi Grab dan Gojek juga ditunjang dengan kemudahan cara mendaftar dari kedua aplikasi ini yang pada gilirannya semakin membuat bertambahnya driver ojek online perempuan. Bagi kaum hawa, menjadi pengemudi ojek online perempuan tidak membutuhkan persyaratan yang begitu susah untuk menggeluti profesi ini. Selain fisik yang mumpuni, pekerjaan ini membutuhkan keuletan dan ketelatenan dalam menjalani pekerjaan. Faktanya mereka justru sangat menekuni profesi menjadi pengemudi ojek online

Dari hasil wawancara yang dilakukan oleh penulis paling tidak terdapat tiga tipologi pengemudi ojek online perempuan dari jenis pekerjaan atau model yang mereka kerjakan setiap harinya. Pertama ada yang fokus mengantarkan penumpang saja. Yang lainnya memilih pengiriman barang, dan terakhir ada juga yang memilih sebagai pengantar makanan atau minuman saja. Ketiga tipologi ini juga berbasis pada rasionalitas perempuan pengemudi ojek yang ketiganya juga didukung mode aplikasi yang berbeda antar satu tipe dengan lainnya. Jika ingin mendapatkan uang cash dalam jumlah yang banyak, maka driver online lebih memilih untuk mengerjakan grab bike atau go ride yang berarti termasuk pada tipologi yang pertama. Alasannya sederhana, karena jenis orderan ini lebih banyak diminati, lebih cepat dalam mendapatkan uang dan langsung saat itu diterima oleh pengemudi dibanding dua tipe lainnya. Selain itu, mitra aplikator dapat memilih tarif yang ditentukan sesuai dengan kesepakatan antara mitra dan konsumen dengan metode offline yang berarti tanpa menggunakan aplikasi.

Bagi para pengemudi perempuan, salah satu kendala yang muncul adalah bilamana mendapat penumpang laki-laki, keduanya baik pengemudi perempuan maupun penumpang menjadi tidak nyaman bahkan cenderung risih. Pada umumnya pengemudi ojek daring perempuan melakukan siasat dengan menanyakan terlebih dahulu kepada penumpang apakah dia bersedia dikendarai oleh supir ojek 
online perempuan, atau dia akan menyetir sendiri dengan posisi driver yang berganti peran sebagai penumpang

Lain halnya dengan pengemudi ojek daring perempuan yang memilih sebagai pengantar orderan makanan atau tipologi kedua. Rasionalitas mereka memilih tipologi ini adalah mereka fokus dalam mengandalkan insentif yang disediakan oleh pihak aplikator. Pilihan pengemudi perempuan pada tipe ini bukan tanpa alasan. Dalam kajian ini, sangat rasional jika menyimpulkan bahwa ojek online perempuan lebih sering memilih metode ini, alasannya adalah bila dibandingkan dengan mengantar penumpang dan barang, kegiatan mengantarkan makanan tidak memerlukan fisik yang lebih seperti mengantarkan penumpang dan barang. Hal tersebut dikarenakan para driver dapat menunggu order yang masuk tidak dengan berkeliling tetapi berdiam di resto yang bermitra dengan grab maupun gojek.

Studi ini mengungkapkan bahwa profesi ojek online perempuan adalah profesi yang tergolong profesi yang dapat menghasilkan uang tanpa memerlukan pendidikan tinggi untuk memenuhinya. Dari hasil wawancara kepada beberapa driver ojek online perempuan, mereka memiliki penghasilan rata-rata Rp.80.000,sampai Rp.150.000,- per hari, tergantung dengan intensitas orderan yang mereka terima pada hari itu. Angka itu jelas terbilang besar dengan nirpendidikan resmi yang harus dimiliki. Meski tergolong besar, akan tetapi muncul pula kekecewaan driver perempuan karena beberapa keputusan pihak manajemen tidak pro terhadap pengemudi bahkan seringkali berubah-ubah. Misalnya salah satunya terkait keputusan peningkatan target insentif pendapatan yang diberlakukan oleh aplikator. Juga terkadang pihak manajemen sering mengubah-ubah skema insentif. Sebagai contoh skema insentif yang diberlakukan oleh salah satu aplikator memang relatif berbeda-beda menyesuaikan daerah dimana aplikator itu berjalan. Skema ini dimulai tahun 2017 dan samapi sekarang masih sering mengubah skema insentif itu sendiri. Juga, perkembangan penggunaan dan bertambahnya driver inilah yang dijadikan acuan bagi pihak aplikator untuk menyesuaikan pendapatan dari perusahaan. Insentif ini merupakan tambahan pendapatan dari manajemen kepada mitra pengemudi. Perubahan insentif juga bergantung pada perubahan kebijakan yang juga sering terjadi dan berbeda tiap tahunnya. (Lihat gambar 2).

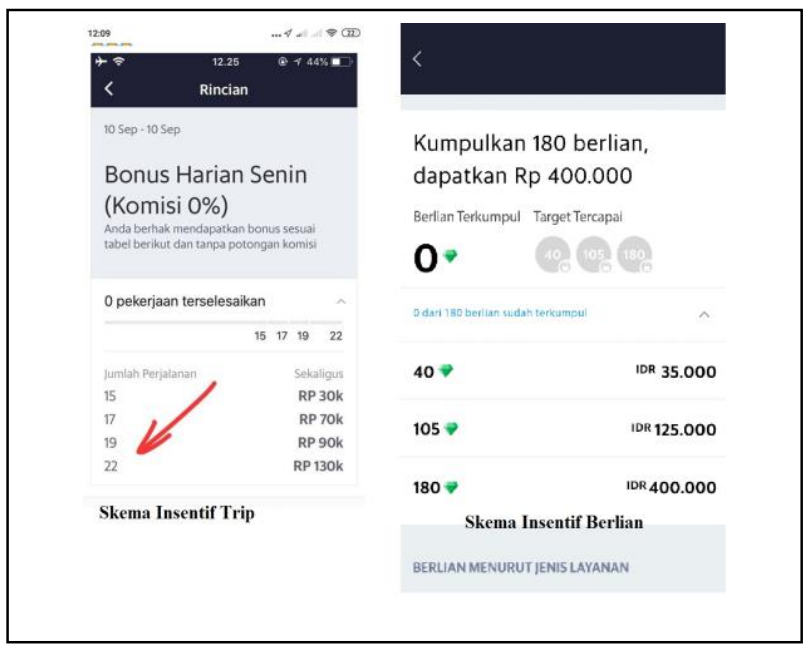

Gambar 2. Perbandingan Skema insentif trip pada tahun 2017-2018 dan Skema berlian yang berlaku pada tahun 2018 akhir Sumber : Dokumen Peneliti

Dari gambar tersebut dapat diketahui bahwa perbedaan skema insentif tersebut adalah bentuk penyesuaian dari skema insentif perjalanan. Pada awalnya insentif diberikan dengan model insentif trip yang berarti bahwa semakin uang yang didapat banyak dalam sekali tripnya maka pendapatan pengemudi online juga relatif tinggi. Dengan konsep ini, pendapatan pengemudi ojek bisa mendapat hingga Rp.300.000,/ hari. Namun secara gradual, kebijakan tersebut berubah dengan menggunakan skema berlian. Bahkan beberapa pengemudi ojek perempuan mengaku merugi dengan kebijakan manajemen yang mengubah skeam tersebut. Dengan pendapatan per hari yang sama, yang didapat pengemudi menjadi jauh berbeda antara skema insentif dan skema berlian, skema insentif 100\% lebih besar daripada skema berlian. 


\section{Pengemudi Ojek Online Perempuan berperspektif Gender sebagai Fungsi Reproduktif.}

Jika melihat dalam perspektif gender dalam menganalisis fungsi perempuan yang fokus pada fungsi reproduktif adalah melihat persoalan dari bagaimana perempuan membagi waktu mereka dengan keluarganya. Konteks dalam kasus artikel ini adalah bagaimana pengemudi ojek online perempuan membagi waktu mereka dan menyesuaikan dengan pekerjaan mereka sebagai perempuan pekerja lapangan. Secara singkat ditemukan data bahwa kebanyakan perempuan yang berprofesi sebagai pengemudi ojek online membagi waktunya dengan memulai pekerjaan di pagi hari setelah mereka menyelesaikan pekerjaan domestiknya seperti mencuci, memasak dan lainnya. Pengemudi ojek online perempuan ini biasanya memulai pekerjaan domestiknya di pagi hari selepas subuh bahkan tak jarang sebelumnya. Biasanya pada pukul 06.00 mereka sudah bersiap untuk menjalankan aktivitas publiknya menjadi pengemudi ojek online. Pilihan rasional mereka beragam, ada yang memanfaatkan momen anak sekolah berangkat ke sekolah, dan ada juga yang memanfaatkan waktu sekaliagus mengantar anak-anak mereka. dan adapula yang memang memanfaatkan waktu tersebut sambil membeli keperluan lainnya.

Ada perempuan yang menjadi profesi ini sebagai profesi utama, atau ada pula yang mengisi waktu luangnya dengan menjadi pengemudi ojek. Bagi mereka yang terpenting adalah perempuan bisa membagi waktu antara pekerjaan domestik dan pekerjaan publik. Dalam perspektif gender, seharusnya perempuan diposisikan sebagai pihak yang seharusnya mendapatkan kesetaraan yang sama yaitu soal waktu dengan para pria. Jumlah prosentase jam kerja perempuan dalam hari juga beragam ada yang berkisar antara 7-9 jam. Bahkan ada pula yang menghabiskan waktunya menjadi pengemudi ojek daring lebih dari 12 jam (lihat tabel 2). Dari hasil penelusuran pula hampir $65 \%$ pengemudi ojek online memilih full time job daripada part time job. Alasannya pun beragam, selain mereka menemukan kecocokan dengan profesi yang mereka lakoni, mereka juga menemukan kepuasan tersendiri melalui pekerjaan pengemudi ojek online. Kecocokan itu muncul dari beberapa faktor mulai dari hobi mereka sebagai pengendara motor, kesenangan memperoleh teman baru, hingga mengisi waktu luang mereka untuk menghilangkan penat. Sebagian pengemudi ojek online perempuan mengungkapkan bahwa dengan berkendara di jalan raya, mereka mempunyai kesempatan menghilangkan kejenuhan akibat tanggung jawab yang berat di dalam rumah tangga.

Bagi Ibu Mistianah salah satu pengemudi online misalnya, dia bekerja sebagai driver ojek online dikarenakan dia mendapatkan izin dari suaminya yang sedang bekerja di luar kota. Momentum kebebasan inilah yang digunakan oleh sesorang tersebut untuk menambah penghasilan selain yang diberikan oleh suami.Menurutnya

"Yah sekalian jalan-jalan dan dapat uang Mas"

Tidak hanya soal ekonomi, rata-rata penghasilan suami yang istrinya bekerja sebagai ojek online sudah dapat mencukupi kehidupan mereka sehari-hari. Dalam studi gender kali ini memang difokuskan bagaimana driver perempuan tersebut mengkontruksikan dirinya di dalam masyarakat terhadap profesinya tersebut dan permasalahan-permasalahan yang timbul sebagai konsekuensi pekerjaan.

\begin{tabular}{cccc} 
No & $\begin{array}{c}\text { Jenis } \\
\text { Pekerjaan }\end{array}$ & \multicolumn{2}{c}{ Jam Kerja (\%) } \\
$\mathbf{7 - 9}$ Jam & $\begin{array}{c}\mathbf{1 2}-\mathbf{1 8} \\
\text { Jam }\end{array}$ \\
\hline 1 & Full Time & $45 \%$ & $55 \%$ \\
\hline \multirow{3}{*}{$\begin{array}{c}\text { Part Time } \\
\text { (Paruh } \\
\text { Waktu) }\end{array}$} & $70 \%$ & \\
\hline
\end{tabular}

Tabel 2. Jumlah jam kerja Driver Ojek Perempuan

Bagi driver online perempuan tentu dia akan menghadapi sebuah permasalahan dalam menjalani pekerjaan mereka. Tabel 3 telah merangkum jenis kasus dan kendala yang dialami oleh driver ojek online perempuan. 


\begin{tabular}{|c|c|c|}
\hline & Jenis Kasus & Penjelasan \\
\hline 1 & $\begin{array}{l}\text { Pelecehan } \\
\text { Seksual } \\
\text { Tindakan }\end{array}$ & $\begin{array}{l}\text { Masalah ini memang tidak } \\
\text { banyak ditemui, namun } \\
\text { tetap saja hal ini akan } \\
\text { menjadi permaslahan } \\
\text { serius, seperti contohnya } \\
\text { ketika driver ojek online } \\
\text { perempuan membawa } \\
\text { penumpang, namun dia } \\
\text { mendapat perlakuan kurang } \\
\text { mengenakkan seperti } \\
\text { diraba anggota tubuhnya } \\
\text { serta menempelkan alat } \\
\text { kelamin laki-laki ke bagian } \\
\text { belakang driver, namun } \\
\text { pelaku masih dibawah } \\
\text { umur dan driver apabila } \\
\text { menurunkan penumpang } \\
\text { tersebut tidak pada } \\
\text { tempatnya akan } \\
\text { mendapatkan hukuman } \\
\text { suspend. } \\
\text { Biasanya penyelesaian ini } \\
\text { driver melaporkan kepada } \\
\text { kantor Grab untuk } \\
\text { dilakukan tindakan kepada } \\
\text { penumpang yang } \\
\text { melakukan tersebut. }\end{array}$ \\
\hline 2 & $\begin{array}{l}\text { Pelecehan } \\
\text { Seksual } \\
\text { Verbal }\end{array}$ & $\begin{array}{l}\text { Masalah ini memang paling } \\
\text { sering terjadi, biasanya } \\
\text { dilakukan oleh sesama } \\
\text { driver atau bahkan dengan } \\
\text { customer. bentuknya } \\
\text { macam-macam seperti } \\
\text { ledekan "Lamar tidak } \\
\text { berjumpa, pantatmu terlihat } \\
\text { tambah seksi" Atau yang } \\
\text { biasanya dilakukan oleh } \\
\text { penumpang yaitu "waduh, } \\
\text { kalau saya keliru pegang di } \\
\text { bagian yang salah } \\
\text { bagaimana mbak?" atau } \\
\text { ledekan "Apakah suamimu } \\
\text { tak mampu memberikan } \\
\text { penghasilan lebih?" Tentu } \\
\text { bagi driver yang tidak } \\
\text { berani melawan atau } \\
\text { memberikan tindakan } \\
\text { kepada pelaku maka akan } \\
\text { mengakibatkan driver akan } \\
\text { depresi dalam menjalani } \\
\text { pekerjaannya. }\end{array}$ \\
\hline 3 & Order Fiktif & $\begin{array}{l}\text { Permasalahan } \\
\text { sebenarnya tidak begitu } \\
\text { memberikan dampak akan }\end{array}$ \\
\hline
\end{tabular}

\begin{tabular}{|c|c|c|}
\hline & \multirow[t]{2}{*}{ Jenis Kasus } & Penjelasan \\
\hline & & $\begin{array}{l}\text { tetapi bagi driver ojek } \\
\text { online perempuan yang } \\
\text { baru memulai tentu akan } \\
\text { menjadikan permaslahan } \\
\text { rumit. Ada sekelumit driver } \\
\text { yang mengeluhkan order } \\
\text { fiktif dalam grab food pada } \\
\text { resto pilihan apabila driver } \\
\text { lupa memindahkan saldo } \\
\text { dari dompet tunai ke } \\
\text { rekening maka saldo yang } \\
\text { masuk ke dalam dompet } \\
\text { kredit atau potongan bagi } \\
\text { driver yang sudah } \\
\text { menyelesaikan orderan } \\
\text { maka uang tidak akan bisa } \\
\text { dicairkan ke rekening. Bagi } \\
\text { aplikator sendiri juga tidak } \\
\text { ada jenis penggantian lain. }\end{array}$ \\
\hline 4 & $\begin{array}{l}\text { Jalanan } \\
\text { adalah Area } \\
\text { Maskulinitas }\end{array}$ & $\begin{array}{l}\text { Bagi para driver ojek online } \\
\text { perempuan, jalanan adalah } \\
\text { pembunuh no satu di dunia. } \\
\text { Kemampuan } \\
\text { perempuan Driver } \\
\text { mengendarai motor juga } \\
\text { tidak sekuat dan setegar } \\
\text { laki-laki. }\end{array}$ \\
\hline 5 & $\begin{array}{l}\text { Penilaian } \\
\text { yang buruk } \\
\text { dari } \\
\text { customer }\end{array}$ & 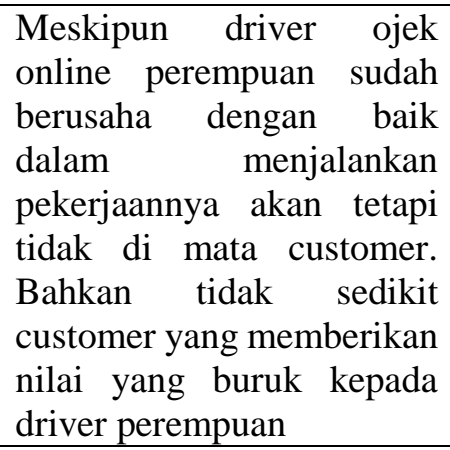 \\
\hline 6 & $\begin{array}{l}\text { Maraknya } \\
\text { kekerasan } \\
\text { dan } \\
\text { Pemalakan } \\
\text { dari Opang }\end{array}$ & $\begin{array}{l}\text { Ojek Pangkalan sering kali } \\
\text { melakukan pemalakan yang } \\
\text { tidak menghiraukan aturan. } \\
\text { Driver ojek online } \\
\text { perempuan pernah menjadi } \\
\text { korban dihadapkan pada } \\
\text { ketidak-berdayaan }\end{array}$ \\
\hline
\end{tabular}

Tabel 3. Kasus yang dialami oleh driver ojek online perempuan

Dari tabel 3 melihat bahwa kasus gender yang dialami oleh ojek online perempuan adalah bentuk ketidak-berdayaan perempuan akibat dominasi yang dilakukan oleh laki-laki. Perempuan dihadapkan pada ketidak-adilan yang dikontruksi sosial terhadap stigma perempuan adalah objek kekerasan. Meski kejadian kasus 
ojek online perempuan kasuistik gender tidak begitu terlihat dan terekspose media, akan tetapi kasus tersebut tetap ada dan perlu dikasi agar tidak menjadi permasalahan sosial.

\section{Konstruksi Sosial Gender Terhadap Profesi Ojek Online Perempuan}

Dalam studi ini konstruksi sosial yang membangun stigma dan stereotip gender kepada profesi ojek online adalah positif. Masyarakat tidak memandang profesi ojek online perempuan sebagai suatu hal yang bersifat negatif, justru masyarakat memandang profesi ojek online perempuan sebagai sebuah keharusan di era revolusi industri 4.0 ini. Biasanya perempuan tidak bisa menggunakan aplikasi GPS dan Maps pada HP Mereka dengan adanya profesi ojek online perempuan, mereka menjadi melek teknologi terhadap aplikasi-aplikasi yang biasanya hanya dipahami oleh kaum lelaki. Stigma perempuan tidak melek teknologi dan tidak bisa menguasai jalanan cair melalui profesi ojek online ini.

Menurut perkembangan, pihak aplikator khususnya grab membuat beberapa kebijakan yaitu diantara driver perempuan akan lebih sering mendapat penumpang atau customer perempuan. Dampak inilah yang sebenarnya menjadi tesis dari penelitian kali ini. Pihak aplikator sudah memulai memperhatikan dampak sosial dari keberadaan profesi ojek online perempuan yang terus bertambah dan akan terus bertambah. Selain dampak itu pihak competitor dari grab dan gojek juga membuat ojek online dengan metode "syar' $i$ " sebagai implikasi dari bias kebutuhan akan driver ojek online perempuan. Seperti contohnya aplikator grab dan gojek adalah syariah jek. Syariah jek aplikator sejenis grab dan gojek yang tergolong baru. Keberadaan profesi ojek online perempuan sangat memberikan bias positif terhadap kebutuhan ketersediaan driver ojek online perempuan pada angkutan umum berbasis online ini. Kebanyakan perempuan dewasa dan anak-anak akan merasa nyaman jika digonceng oleh pengemudi yang ber-jenis kelamin sama. Selain itu, konsumen perempuan juga merasa nyaman apabila dibonceng sesama perempuan dengan alasan lebih hati-hati dalam berkendara. Selain itu, sebagian merasa senang dikarenakan simbol profesi ojek online perempuan adalah bentuk perjuangan kemandirian pada kaum perempuan untuk bertahan hidup di era yang membutuhkan kreatifitas ini.

Pada bulan maret 2019 paguyuban driver grab dan gojek se-kota Malang bersatu untuk melaksanakan demo menuntut pemberlakuan kenaikan tarif. Peran driver ojek online perempuan dalam keberlangsungan perjuangan driver menuntut kenaikan tarif sangat sentral. Dalam posisi menyampaikan aspirasi figure perempuan menjadi pusat perhatian dan menjadi perhitungan pihak aplikator. Perempuan adalah simbol kekuatan feminis dari sebuah pergerakan. Tapi, ibaratkan pisau bermata dua sisi lain driver menuntut kesejahteraan mereka dipenuhi oleh pihak aplikator, sisi lain jika tarif sudah naik customer akan merasa keberatan dan bisa saja beralih ke angkutan konvensional lagi. Studi ini berlanjut pada tanggal 12 Agustus 2019 yang lalu bahwa ketetapan mentri perhubungan menaikkan tarif ojek online sebesar 100\% tarif ini dirasakan sangat memberatkan konsumen. dan berakibat sepinya orderan.

Bagi pihak gojek maupun grab alangkah baiknya lebih memperhatikan kehidupan dan perlindungan bagi profesi ojek online perempuan. Perempuan tidak hanya sebagai alat untuk promosi saja tetapi harus dilindungi hakhaknya.

\section{Konstruksi Sosial Gender}

Peran ilmu sosial harus menjadikan gender dalam kacamata third sex, Muqoyyin (2013) memandang gender adalah bukan dari kemampuan fisikal saja. Maksud dari kasus ini adalah bahwa Ojek online perempuan bukanlah suatu objek studi untuk semakin membuat jeda antara laki-laki dan perempuan. Tapi menciptakan bentuk perlindungan sosial dan kontribusi sosial nyata. Dukungan terhadap pernyataan berikut adalah Irwan (2003) mengemukakan konteks gender tersebut sebagai kontruksi sosiokultural yang membedakan jenis kelamin. Peran sosiokultural dalam mengurangi alineasi pemisah antara konsep ojek online lakilaki dan perempuan dapat diminimalisir. 
Iswantini (2017) beranggapan bahwa driver ojek online perempuan adalah soal memperbaiki stereotip yang beredar di masyarakat bahwa profesi tukang ojek adalah profesi yang tidak pantas dilakukan oleh kaum hawa karena keterbatasan fisik. Segmentasi pasar yang telah beredar di masyarakat bahwa tukang ojek online perempuan adalah bukan untuk dikasihani akan tetapi posisinya harus mendapatkan perlindungan hukum ataupun kontruksi sosial yang tidak memihak. Mengutip yang dikatakan oleh Fatimah (2012) bahwa melemahnya institusi lokal akan mengakibatkan melemahnya kontrol rakyat terhadap Negara. Menurutnya, menonjolnya simbol-simbol tentang perempuan dalam perspektif patriarki yang diciptakan Negara berkamuflase untuk menciptakan paradigma bahwa Negara melindungi hak-hak perempuan, akan tetapi sebenarnya melemahkan konteks dari peran perempuan itu sendiri, terutama dalam sektor publik

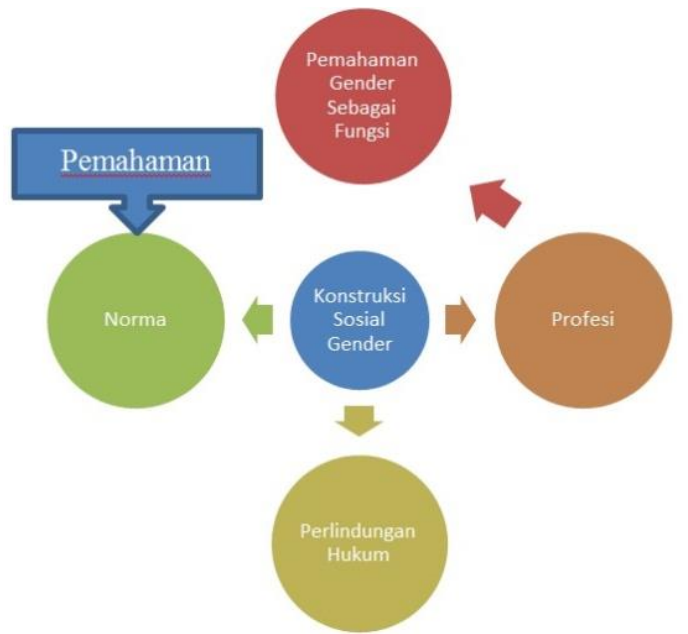

Gambar 3. Bagan Inti temuan dari studi gender pada profesi ojek online perempuan

Pemahaman dan norma terhadap konstruksi sosial terhadap gender adalah proses pembentukan terhadap norma. Selama memandang kesetaraan bahwa driver perempuan sama dengan laki-laki. Meminimalkan tindak kejahatan terhadap perempuan tentu berawal dari normatif terhadap pemahaman konteks gender pada profesi. Foucault juga beranggapan bahwa kultur yang dibentuk dalam sebuah kesepahaman dan rasionalitas yang ada dalam masyarakat bahwa pengayaan gender yang terbangun melalui asumsi yang beredar bahwa wanita tidak cocok bekerja sebagai lapangan. Bagi Foucault identitas dalam diri juga sebagai perwujudan identitas semu karena bentukan sosial dalam membentuk identitas mereka sebagai perempuan dibangun dalam jaringan kultur masyarakat.

\section{PENUTUP}

Gender adalah bukan kasus sosial untuk mendapatkan bantuan, akan tetapi menciptakan kesadaran masyarakat terhadap sebuah fenomena yang tidak bisa dihindari lagi. Profesi ojek online menuntut kemandirian setiap penggunanya. Apalagi dalam kasus ini adalah perempuan. Profesi dalam fungsinya adalah menumbuhkan produktifitas, perempuan adalah batasan. Penguatan komunitas dan jejaring sosial bagi profesi ojek online perempuan akan membuat perlindungan bagi profesi tersebut. Selain itu pemahaman dimasyarakat untuk tidak membedakan keterbatasan fisik antara pria dan perempuan..

\section{DAFTAR RUJUKAN}

Abdullah, I., 2003. Penelitian berwawasan gender dalam ilmu sosial. Jurnal Humaniora, 15(3), pp.265-275

Anindhita, W., Arisanty, M. and Rahmawati, D., 2016, November. Analisis Penerapan Teknologi Komunikasi Tepat Guna Pada Bisnis Transportasi Ojek Online (Studi pada Bisnis Gojek dan Grab Bike dalam Penggunaan Teknologi Komuniasi Tepat Guna untuk Mengembangkan Bisnis Transportasi). In Prosiding Seminar Nasional INDOCOMPAC.

Anwar, A.A., 2017. Online vs konvensional: keunggulan dan konflik antar moda transportasi di kota makassar. ETNOSIA: Jurnal Etnografi Indonesia, 2(2), pp.220-246.

Handajani, H., Relawati, R. and Handayanto, E., 2016. Peran gender dalam keluarga nelayan tradisional dan implikasinya pada model pemberdayaan perempuan di Kawasan Pesisir Malang Selatan. Jurnal Perempuan \& Anak, 1(1). 
Iswantini, W., 2017. Customer Satisfaction As Mediation Variables Between Perceptions Of Perception Of Quality And Image Of Companies With Consumer Loyalty (Study Of Consumer Comparison Online And Non-Ojek Online)

Marhumah, E., 2011. Konstruksi Sosial Gender di Pesantren; Studi Kuasa Kiai Atas Wacana Perempuan. LKIS PELANGI AKSARA.

Muqoyyidin, A.W., 2013. Wacana Kesetaraan Gender: Pemikiran Islam Kontemporer tentang Gerakan Feminisme Islam. AlUlum, 13(2), pp.490-511

Megantara, F. and Warnars, H.L.H.S., 2016. Implementasi Big Data untuk pencarian pattern data gudang pada PT. Bank Mandiri (Persero) TBK. Jurnal SISFOTEK GLOBAL, 6(2).

Nugroho, D.G., Chrisnanto, Y.H. and Wahana, A., 2016. Analisis Sentimen Pada Jasa Ojek Online Menggunakan Metode Naïve Bayes. Prosiding SNST Fakultas Teknik, 1(1).

Qoriah, S.N. and Sumarti, T., 2008. Analisis gender dalam program desa mandiri pangan (studi kasus: Desa Jambakan, Kecamatan Bayat, Klaten-Jawa Tengah). Sodality: Jurnal Sosiologi Pedesaan, 2(2).
Perguna, L.A,. (2019). Dua Kaki Perempuan Lansia antara Diskriminasi Ganda dan Mencari Pahala (Studi Kasus di Pondok Sepuh Kabupaten Magelang). Jurnal Marwah, 18 (2), 1-15. Retrived http://ejournal.uin-suska.ac.id/index. $\mathrm{php} / \mathrm{marwah} / \mathrm{article} / \mathrm{view} / 7170$

Rifaldi, R., Kadunci, K. and Sulistyowati, S., 2016. Pengaruh Kualitas Pelayanan Transportasi Online Gojek Terhadap Kepuasan Pelanggan Pada Mahasiswa/i Administrasi Niaga Politeknik Negeri Jakarta. Epigram, 13(2).

Rosa, D. (2017). Ruang Negosiasi Perempuan di Balik Revolusi Kopi Using. Jurnal Sosiologi Pendidikan Humanis, 2(2), $63 \quad$-73. Retrieved from http://journal2.um.ac.id/index.php/jsph /article/view/3397

Verasatiwi, I. and Wulan, R.R., 2018. Studi Fenomenologi Pengemudi Ojek Online Perempuan Di Kota Bandung Dalam Kajian Feminisme. Journal Acta Diurna, 14(1). 